7 - ORIGINAL ARTICLE

ISCHEMIA-REPERFUSION

\title{
Renal biomarkers of male and female Wistar rats (Rattus norvegicus) undergoing renal ischemia and reperfusion ${ }^{1}$
}

\author{
Telma Bazzano ${ }^{\mathrm{I}}$, Tamy Ingrid Restel ${ }^{\mathrm{II}}$, Lenir Cardoso Porfirio ${ }^{\mathrm{III}}$, Albert Schiaveto de Souza ${ }^{\mathrm{IV}}$, Iandara Schettert Silva ${ }^{\mathrm{V}}$
}

DOI: http://dx.doi.org/10.1590/S0102-865020150040000007

IFellow PhD degree, Postgraduate Program in Health and Development of the Midwest, Federal University of Mato Grosso do Sul (UFMS), Campo Grande-MS, Brazil. Acquisition and interpretation of data, manuscript preparation.

IMaster, Technician, Central Animal Facility, UFMS, Campo Grande-MS, Brazil. Technical procedures.

IIIPhD, Associate Professor, Department of Veterinary Medicine, Federal University of Espirito Santo (UFES), Vitoria-ES, Brazil. Veterinary assistance in the execution of the urinary biochemical analysis, manuscript preparation.

${ }^{\mathrm{IV}} \mathrm{PhD}$, Associate Professor, Center for Biological and Health Sciences, UFMS, Campo Grande-MS, Brazil. Statistical analysis.

${ }^{v} \mathrm{PhD}$, Associate Professor, Postgraduate Program in Health and Development of the Midwest, UFMS, Campo Grande-MS, Brazil. Conception and design of the study, surgical procedures.

\section{ABSTRACT}

PURPOSE: To investigate biomarkers of acute renal injury in Wistar rats, subjected to left renal ischemia for 10 minutes, and then compare reperfusion at 24 hours, and at 5, 7, 14 and 21 days after the procedure.

METHODS: Eight female and male rats between 60 and 81 days old were used in the Central Animal Facility of the UFMS. Assessed biomarkers included urine protein, urea, creatinine, glucose, sodium, potassium, urine alkaline phosphatase and gamma-glutamyl transferase activities, and protein-to-creatinine ratio; and in serum: urea, creatinine, sodium and potassium, fractional excretion of sodium, potassium, urine flow and creatinine clearance.

RESULTS: Greater variance was observed in the parameters at 24 hours and at five days $(\mathrm{p}<0.05)$ after reperfusion. On the $21^{\text {st }}$ day, these parameters approximated those obtained for the control group.

CONCLUSIONS: Renal ischemia for 10 minutes was sufficient to raise urine levels of protein, glucose, fractional excretion of potassium, urea, creatinine clearance, urine activity of gamma-glutamyltransferase and alkaline phosphatase enzymes in the first 24 hours, up to five days after reperfusion, which may indicate risk of acute kidney injury, according to the RIFLE classification.

Key words: Biomarkers, Pharmacological. Ischemia. Reperfusion. Kidney. Rats. 


\section{Introduction}

Renal ischemia and reperfusion (I/R) consists of clamping the renal artery or pedicle for a period of 15 to 60 minutes, with the subsequent clearance of the occluded vessel and restored blood flow, reproducing the clinical model of kidney transplantation. The applicability and viability of this model result from the similarity of inflammatory response, medullary congestion, and tubular injury presented when compared to data obtained from the renal biopsy of patients with Acute Kidney Injury (AKI) ${ }^{1}$. Diverse animal and clinical studies show renal tolerance of ischemia beyond 30 minutes, but there are concerns as to whether total recovery is possible after this period ${ }^{2}$. Ischemia-induced renal failure was observed one day after reperfusion was performed in male and female rats, though these renal lesions were more evident in males than in females ${ }^{3}$.

Due to a lack of early renal markers to be applied to medical practice ${ }^{4}$, and the relative insensitivity of traditional clinical tests in assessing renal function to accomplish early detection of an injury or altered renal function, there is considerable interest in potential biomarkers of the early effect of renal injury ${ }^{5}$. Additionally, because there is no consensus regarding $\mathrm{AKI}^{4}$, the RIFLE classification (Risk, Injury, Failure, Loss of kidney function, and End-stage kidney disease), in which urinary output is included as a renal assessment measure, was developed. Subsequently, this criterion was replaced by the AKIN classification to enable an earlier diagnosis of renal injury and earlier staging of acute kidney injuries ${ }^{6}$.

This study's aim was to analyze renal biomarkers through the biochemical analysis of the urine of male and female Wistar rats (Rattus norvegicus) submitted to unilateral left renal ischemia for a period of 10 minutes and then compare reperfusion at 24 hours, and at 5, 7, 14 and 21 days after the procedure with the nonischemic control group.

\section{Methods}

This study was approved by the Institutional Review Board regulating the use of animals (CEUA) at the Federal University of Mato Grosso do Sul (Protocol CEUA/UFMS No. 358/2011).

A total of 16 male and female rats (Rattus norvegicus), of conventional Wistar lineage, originating from the Central Animal Facility at the Technical Unit of the Biological Sciences and Health Center (UFMS) were used in this study. The animals were randomly distributed into two groups: Control group, divided into females $(n=4)$ and males $(n=4)$ and the I/R Experimental group also, distributed into females $(n=4)$ and males $(n=4)$. The project was developed at six different points in time when the rats were between 60 and 81 days old. The animals were placed into

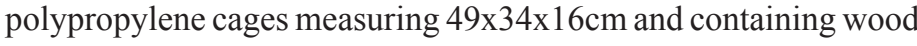
chips, arranged on shelves. Each cage contained four animals of the same sex up to the time of the surgical procedure, in the case of the I/R group. To collect blood and urine samples, animals of both groups were individually placed in a metabolic cage.

The animals were kept in an acclimatized room with conventional environmental conditions controlled for temperature and humidity with the use of a thermo-hygrometer and a photoperiod with timer, respecting the daily cycle of rodents, i.e., 12 hours/day and 12 hours/night. They were fed a balanced commercial diet of CR-1 Nuvital/Nuvilab ${ }^{\circledR}$ that is specific for this species and were given ad libidum access to water. Before each procedure, the animals were weighed on a Gehaka ${ }^{\circledR}$ three digit electronic scale.

The entire routine of cleaning the macro- and microenvironment, and maintaining the animals and all the experimental procedures performed at different times, met the operational standards established by the Animal Facility - UT/CCBS/ UFMS, in accordance with Law No. 11.794, from October $8^{\text {th }}$, 2008, Normative Instruction of the National Council on Animal Experimentation (CONCEA) and the Brazilian Guidelines for the Care and Use of Animals for Scientific and Teaching Purposes (DBCA).

To contain the animals and for the anesthetic protocol, we used a combination of intramuscular Xylarine $(5 \mathrm{mg} / \mathrm{kg})$ and Ketamine $(20 \mathrm{mg} / \mathrm{kg})$. Hair was removed from the left flank region and asepsis was performed with alcohol at $70 \%$ concentration, enabling surgical access.

Aiming to test a 10-minute ischemia through venous and arterial stenosis and reperfusion at 24 hours, 5, 7, 14 and 21 days after the procedure, the surgery (I/R) with an aseptic technique was performed through laparotomy on the left flank to access the kidney, which was exposed to remove the perirenal fat. After isolating the pedicle, the renal artery and vein were clamped with non-traumatic forceps, minimizing damage to the adventitia layer.

During the 10 minutes, ischemia was visually verified by the change in kidney color. Reperfusion was initiated and confirmed by the recovery of the organ's initial color. After verifying hemostasis, the kidney was reallocated and closure was immediately performed with needled 4.0 monofilament nylon thread. The animals were monitored until they totally recovered from anesthesia. 
Renal function was assessed after reperfusion at 24 hours, and at 5, 7, 14 and 21 days with laboratory exams of biomarkers of protein, urea, creatinine, glucose, sodium, potassium, urinary activity of alkaline phosphatase (ALP), gamma-glutamyl transferase (GGT) and urine protein-to-creatinine ratio assessed in their urine; and in serum: urea, creatinine, sodium and potassium; and also fractional excretion of sodium, potassium, urinary flow and creatinine clearance.

A volume of $0.5 \mathrm{~mL}$ of blood was collected through the retro-orbital plexus and placed in an Eppendorf tube without anticoagulant and with accelerator gel; it was submitted to centrifugation at $2000 \mathrm{rpm}$ (Fanen ${ }^{\circledR}$ centrifuge) for 10 minutes to obtain serum-free hemolysis. After separation of the serum, the samples were frozen at $-20^{\circ} \mathrm{C}$ until the exams were performed, when they were thawed to room temperature and urea, creatinine, sodium, potassium, and serum glucose were quantified in a Cobas ${ }^{\circledR}$ Integras 400 biochemical device in the Clinical Analysis Laboratory at NHU/ UFMS.

A volume of $2.0 \mathrm{~mL}$ of urine was collected at 24 hours after reperfusion using metabolic cages and stored in Eppendorf tubes, which were then frozen for photometrical biochemical analysis in Bioplus $2000^{\circledR}$ equipment in the Analysis Laboratory at the Veterinary Clinics Hospital at the Federal University of Espirito Santo (UFES). After the urine samples were thawed to room temperature, the concentration of protein in the urine was measured with the Sensiprot Kit $\left(\right.$ Labtest $\left.^{\mathbb{R}}\right)$ using the colorimetric method of pyrogallol red, Ref.36 Sensiprot. In order to quantify urine creatinine, 1:50 dilution was performed according to the Jaffe reaction Ref. 96, Creatinine K. Urea was measured with urine diluted to $1: 50$ by colorimetric enzymatic hydrolysis by the urease system, Ref. 27, Urea CE. Alkaline phosphatase urine activity was measured through the kinetic method of hydrolysis of p-nitrophenyl phosphate, Ref. 79, Alkaline Phosphatase Liquiform. Urine gamma-glutamyltransferase (GGT) was quantified in kinetic mode by transference of the glutamyl group of L-y-glutamyl-3carboxy-4-nitroanilide for the glycylglycine, Ref. 105, gamma GT Liquiform.

Glomerular filtration was assessed by creatinine clearance based on serum and urine creatinine levels, with values expressed in $\mathrm{mL} / \mathrm{min}$, computed with the formula: $C l c r=$ urine creatinine $(\mathrm{mg} / \mathrm{dL})$ x urine flow $(\mathrm{mL} / \mathrm{min}) /$ Serum creatinine $(\mathrm{mg} / \mathrm{dL})$.

Urine flow was calculated dividing 24 hours of urine volume by 1,440 , which corresponds to the number of minutes in 24 hours $(60 \mathrm{~min} \times 24 \mathrm{~h}=1,440)$ : urine flow $(\mathrm{mL} / \mathrm{min})=$ value of urine volume $(24 h) / 1,440$.
To calculate the fractional excretion of sodium (FENa), we used the values of the variables of urine and serum sodium $(\mathrm{mEq} / \mathrm{L})$, urine and serum creatinine $(\mathrm{mg} / \mathrm{dL})$, using the formula: FENa $(\%)=$ (urine/serum sodium) / (urine/serum creatinine) $X$ 100.

The values of the fractional excretion of potassium (FEK) were obtained through values of urine and serum potassium $(\mathrm{mEq} / \mathrm{L})$, urine and serum creatinine $(\mathrm{mg} / \mathrm{dL})$, with the following formula: FEK $(\%)=$ (urine/serum potassium) / (urine/serum creatinine) $X 100$.

The "urine protein-to-urine creatinine ratio (mg/dL)"(UP/ $\mathrm{UCr}$ ) was obtained by dividing urine protein by urine creatinine at 24 hours, and at 5, 7, 14 and 21 days after the procedure.

Upon project completion, the animals were euthanized with a lethal dose of barbiturate, thiopental sodium, intraperitoneally with a dosage of $150 \mathrm{mg} / \mathrm{kg}$. After euthanasia, both kidneys were removed for weighing and to measure their length and width. The kidneys were sent to the histological Laboratory of the Biological and Health Sciences Center at UFMS. The slides were analyzed in the Animal Pathology Laboratory at UFES using an Olympus ${ }^{\circledR} \mathrm{CX}$ 41 light microscope.

Comparison among the analyses in both groups and both sexes was performed using ANOVA repeated measures, followed by the Tukey post hoc test. The remaining results concerning the variables assessed in this study are descriptively presented. The statistical analysis was performed using SigmaStat, version 2.0, considering a level of significance at $5 \%$.

\section{Results}

Ischemia/reperfusion increased the levels of urine protein (Table 1) in both sexes (ANOVA repeated measures, $\mathrm{p}<0.001$ ). In the females, this increase was more evident 21 days after the procedure, while among the males, such an increase occurred on the $7^{\text {th }}$ day (Tukey, $p<0.05$ ). There was no change in the levels of protein in any of the control group individuals, female or male, at the different points in time $(\mathrm{p}>0.05)$. 
TABLE 1 - Mean \pm Standard Error of Protein (mg/dL) of urine of rats submitted to unilateral left ischemia for $10 \mathrm{minutes}$ and analysis of perfusion 24 hours and 5, 7, 14 and 21 days after the procedure.

\begin{tabular}{ccccc}
\hline \multirow{2}{*}{ Variable/ Points in time } & \multicolumn{2}{c}{ Group Control } & \multicolumn{2}{c}{ Group Experiment I/R } \\
\cline { 2 - 5 } & Female & Male & Female & Male \\
\hline $24 \mathrm{~h}$ & $10.88 \pm 4.17 \mathrm{a}$ & $23.35 \pm 4.89 \mathrm{a}$ & $43.38 \pm 1.76 \mathrm{c}$ & $56.01 \pm 4.57 \mathrm{c}$ \\
$5 \mathrm{~d}$ & $8.20 \pm 0.52 \mathrm{a}$ & $15.11 \pm 4.56 \mathrm{a}$ & $77.36 \pm 5.53 \mathrm{~b}$ & $127.80 \pm 3.01 \mathrm{a}$ \\
$7 \mathrm{~d}$ & $8.28 \pm 0.53 \mathrm{a}$ & $23.15 \pm 7.69 \mathrm{a}$ & $93.92 \pm 7.91 \mathrm{ab}$ & $88.37 \pm 10.17 \mathrm{~b}$ \\
$14 \mathrm{~d}$ & $13.81 \pm 1.94 \mathrm{a}$ & $19.95 \pm 7.92 \mathrm{a}$ & $106.16 \pm 5.46 \mathrm{a}$ & $80.83 \pm 4.31 \mathrm{~b}$ \\
$21 \mathrm{~d}$ & $20.01 \pm 4.76 \mathrm{a}$ & $13.45 \pm 2.20 \mathrm{a}$ & $<0.001$ & $<0.001$ \\
\hline
\end{tabular}

Different letters in the columns represent significant differences among the different points in time verified in Tukey Posttest.

Ischemia/reperfusion increased urine urea (Table 2) only among males on the $21^{\text {st }}$ day, when compared to the remaining points in time (Tukey, $\mathrm{p}<0.05$ ). Even though the ANOVA repeated measures presented a significant $\mathrm{p}$-value in the analysis comparing the different points in time, there was no difference among these points in time among females ( $\mathrm{p}=0.047$ ), according to the multiple comparisons test (Tukey, $\mathrm{p}>0.05$ ). The same was observed among the males in the control group.

TABLE 2 - Mean \pm Standard Error of Urea $(\mathrm{mg} / \mathrm{dL})$ of urine of rats submitted to unilateral left ischemia for 10 minutes and analysis of perfusion 24 hours and 5, 7, 14 and 21 days after the procedure.

\begin{tabular}{ccccc}
\hline \multirow{2}{*}{ Variable/Points in time } & \multicolumn{2}{c}{ Group Control } & \multicolumn{2}{c}{ Group Experiment I/R } \\
\cline { 2 - 5 } & Female & Male & Female & Male \\
\hline $24 \mathrm{~h}$ & $774.89 \pm 84.06 \mathrm{a}$ & $636.45 \pm 61.97 \mathrm{a}$ & $453.84 \pm 110.56 \mathrm{a}$ & $428.72 \pm 18.57 \mathrm{~b}$ \\
$5 \mathrm{~d}$ & $1169.33 \pm 97.71 \mathrm{a}$ & $897.91 \pm 51.45 \mathrm{a}$ & $405.56 \pm 92.39 \mathrm{a}$ & $504.80 \pm 92.27 \mathrm{~b}$ \\
$7 \mathrm{~d}$ & $1130.16 \pm 94.26 \mathrm{a}$ & $1482.45 \pm 294.57 \mathrm{a}$ & $1514.25 \pm 276.08 \mathrm{a}$ & $1855.89 \pm 370.21 \mathrm{~b}$ \\
$14 \mathrm{~d}$ & $1218.45 \pm 247.83 \mathrm{a}$ & $1822.63 \pm 232.18 \mathrm{a}$ & $1362.23 \pm 130.59 \mathrm{a}$ & $3976.29 \pm 1099.78 \mathrm{ab}$ \\
$21 \mathrm{~d}$ & $1096.24 \pm 142.55 \mathrm{a}$ & $1753.23 \pm 343.41 \mathrm{a}$ & $2692.00 \pm 1154.12 \mathrm{a}$ & $7490.74 \pm 2175.25 \mathrm{a}$ \\
P-value & 0.26 & 0.003 & 0.047 & 0.002 \\
\hline
\end{tabular}

Different letters in the columns represent significant differences among the different points in time verified in Tukey Posttest.

In regard to urine creatinine (Table 3 ), I/R induced decreased values at 24 hours in both sexes and later induced a significant increase in the values of males, which was more evident on the $7^{\text {th }}$ and $14^{\text {th }}$ days (Tukey, $\mathrm{p}<0.05$ ). Among the females, even though the urine level of creatinine reached 42.50 $\mathrm{mg} / \mathrm{dL}$ on the $14^{\text {th }}$ day, there was no significant differences among the different points in time (ANOVA repeated measures, $\mathrm{p}=0.109$ ). No changes were observed in creatinine levels over time in the control group, males or females $(\mathrm{p}=0.666$ and $\mathrm{p}=0.919$, respectively).

TABLE 3 - Mean \pm Standard Error of Creatinine - CrU (mg/dL) of urine of rats submitted to unilateral left ischemia for 10 minutes and analysis of perfusion 24 hours and 5, 7, 14and 21 days after the procedure.

\begin{tabular}{ccccc}
\hline \multirow{2}{*}{ Variable/Points in time } & \multicolumn{2}{c}{ Group Control } & \multicolumn{2}{c}{ Group Experiment I/R } \\
\cline { 2 - 5 } & Female & Male & $7.83 \pm 2.14 \mathrm{a}$ & Male \\
\hline $24 \mathrm{~h}$ & $45.12 \pm 7.28 \mathrm{a}$ & $36.65 \pm 3.10 \mathrm{a}$ & $3.32 \pm 1.11 \mathrm{a}$ & $4.42 \pm 1.57 \mathrm{~b}$ \\
$7 \mathrm{~d}$ & $37.60 \pm 6.98 \mathrm{a}$ & $40.21 \pm 6.85 \mathrm{a}$ & $17.38 \pm 2.70 \mathrm{a}$ & $22.42 \pm 0.90 \mathrm{~b}$ \\
$7 \mathrm{~d}$ & $36.18 \pm 3.98 \mathrm{a}$ & $36.62 \pm 5.26 \mathrm{a}$ & $42.50 \pm 21.70 \mathrm{a}$ & $19.63 \pm 3.58 \mathrm{a}$ \\
$21 \mathrm{~d}$ & $43.89 \pm 5.00 \mathrm{a}$ & $35.57 \pm 4.31 \mathrm{a}$ & $19.25 \pm 3.61 \mathrm{a}$ & $17.50 \pm 2.50 \mathrm{ab}$ \\
P-value & $40.59 \pm 7.64 \mathrm{a}$ & $37.55 \pm 5.72 \mathrm{a}$ & 0.109 & 0.003 \\
\hline
\end{tabular}

Different letters in the columns represent significant differences among the different points in time verified in Tukey Posttest. 
Unilateral renal ischemia for 10 minutes revealed levels at 24 hours and 5 days after the procedure; levels started significant differences in creatinine clearance (Table 4) among increasing again from the $7^{\text {th }}$ to the $21^{\text {st }}$ day, with similar values in females $(p=0.002)$ and males $(p=0.015)$, with a sharp decrease in the control group.

TABLE 4 - Mean \pm Standard Error of Creatinine Clearance - Clcr of rats submitted to unilateral left ischemia for 10 minutes and analysis of perfusion 24 hours and 5, 7, 14 and 21 days after the procedure.

\begin{tabular}{ccccc}
\hline \multirow{2}{*}{ Variable/Points in time } & \multicolumn{2}{c}{ Group Control } & \multicolumn{2}{c}{ Group Experiment I/R } \\
\cline { 2 - 5 } & Female & Male & Female & Male \\
\hline $0 \mathrm{~h}$ & $0.4225 \pm 0.9132 \mathrm{a}$ & $0.4450 \pm 0.1297 \mathrm{a}$ & $0.9750 \pm 0.1790 \mathrm{a}$ & $0.9750 \pm 0.3810 \mathrm{a}$ \\
$24 \mathrm{~h}$ & $0.5550 \pm 0.1181 \mathrm{a}$ & $0.8875 \pm 0.2671 \mathrm{a}$ & $0.0725 \pm 0.3146 \mathrm{~b}$ & $0.0275 \pm 0.0075 \mathrm{~b}$ \\
$5 \mathrm{~d}$ & $0.2200 \pm 0.0489 \mathrm{a}$ & $0.7875 \pm 0.1748 \mathrm{a}$ & $0.0750 \pm 0.0419 \mathrm{~b}$ & $0.0975 \pm 0.0347 \mathrm{~b}$ \\
$7 \mathrm{~d}$ & $0.3575 \pm 0.0751 \mathrm{a}$ & $0.6375 \pm 0.2329 \mathrm{a}$ & $0.2375 \pm 0.0292 \mathrm{~b}$ & $0.2400 \pm 0.1096 \mathrm{ab}$ \\
$14 \mathrm{~d}$ & $0.5600 \pm 0.1563 \mathrm{a}$ & $0.6000 \pm 0.0974 \mathrm{a}$ & $0.4925 \pm 0.2738 \mathrm{ab}$ & $0.2375 \pm 0.0747 \mathrm{ab}$ \\
21d & $0.2950 \pm 0.0290 \mathrm{a}$ & $0.6800 \pm 0.3007 \mathrm{a}$ & $0.2750 \pm 0.0987 \mathrm{~b}$ & $0.2375 \pm 0.0543 \mathrm{ab}$ \\
P-value & 0.116 & 0.625 & 0.002 & 0.015 \\
\hline
\end{tabular}

Different letters in the columns represent significant differences among the different points in time verified in Tukey Posttest.

In regard to the mean values of urine ALP (Table 5) This parameter continued to be significantly high up to the $5^{\text {th }}$ activity, the I/R caused significant differences among the experimental day, when values started equalizing with those different points in time in both females and males $(\mathrm{p}<0.001)$. from the control group.

TABLE 5 - Mean \pm Standard Error of Alkaline Phosphatase - ALP (U/L) of urine of rats submitted to unilateral left ischemia for 10 minutes and analysis of perfusion 24 hours and 5, 7, 14 and 21 days after the procedure.

\begin{tabular}{ccccc}
\hline Variable/Points in time & \multicolumn{2}{c}{ Group Control } & \multicolumn{2}{c}{ Group Experiment I/R } \\
\cline { 2 - 5 } & Female & Male & Female & $91.89 \pm 17.63 \mathrm{a}$ \\
$24 \mathrm{~h}$ & $5.18 \pm 0.87 \mathrm{a}$ & $7.26 \pm 0.35 \mathrm{a}$ & $112.85 \pm 13.39 \mathrm{a}$ & $73.94 \pm 3.45 \mathrm{a}$ \\
$5 \mathrm{~d}$ & $4.39 \pm 0.87 \mathrm{a}$ & $6.64 \pm 0.73 \mathrm{a}$ & $95.44 \pm 11.84 \mathrm{a}$ & $3.11 \pm 0.87 \mathrm{~b}$ \\
$7 \mathrm{~d}$ & $8.36 \pm 1.61 \mathrm{a}$ & $10.01 \pm 1.45 \mathrm{a}$ & $6.22 \pm 2.29 \mathrm{~b}$ & $5.47 \pm 1.86 \mathrm{~b}$ \\
$14 \mathrm{~d}$ & $5.80 \pm 0.48 \mathrm{a}$ & $6.44 \pm 0.67 \mathrm{a}$ & $4.84 \pm 1.20 \mathrm{~b}$ & $4.90 \pm 1.69 \mathrm{~b}$ \\
21d & $6.44 \pm 0.67 \mathrm{a}$ & $7.90 \pm 1.66 \mathrm{a}$ & $2.07 \pm 0.69 \mathrm{~b}$ & $<0.001$ \\
P-value & 0.113 & 0.215 & $<0.001$ & $<$ \\
\hline
\end{tabular}

Different letters in the columns represent significant differences among the different points in time verified in Tukey Posttest.

The I/R effect also showed significant differences in GGT urine (Table 6) activity among the different points in time in females $(\mathrm{p}=0.003)$ and males $(\mathrm{p}<0.001)$. According to the experimental period, the animals experience a tendency to decrease at 24 hours and reached levels similar to or lower than those presented by the control group on the $21^{\text {st }}$ day.

TABLE 6 - Mean \pm Standard Error of Gamma-Glutamiltransferase - GGT (U/L) of urine of rats submitted to unilateral left ischemia for 10 minutes and analysis of perfusion 24 hours and 5, 7, 14 and 21 days after the procedure.

\begin{tabular}{ccccc}
\hline \multirow{2}{*}{ Variable/Points in time } & \multicolumn{2}{c}{ Group Control } & \multicolumn{2}{c}{ Group Experiment I/R } \\
\cline { 2 - 5 } & Female & Male & Female & Male \\
\hline $24 \mathrm{~h}$ & $13.03 \pm 1.02 \mathrm{a}$ & $35.54 \pm 16.70 \mathrm{a}$ & $64.24 \pm 18.88 \mathrm{a}$ & $143.98 \pm 15.76 \mathrm{a}$ \\
$5 \mathrm{~d}$ & $11.19 \pm 0.55 \mathrm{a}$ & $35.39 \pm 15.24 \mathrm{a}$ & $43.98 \pm 10.52 \mathrm{ab}$ & $56.98 \pm 6.55 \mathrm{~b}$ \\
$7 \mathrm{~d}$ & $16.91 \pm 3.07 \mathrm{a}$ & $29.64 \pm 8.91 \mathrm{a}$ & $28.88 \pm 3.11 \mathrm{ab}$ & $31.88 \pm 5.15 \mathrm{~b}$ \\
$14 \mathrm{~d}$ & $23.03 \pm 6.82 \mathrm{a}$ & $23.66 \pm 7.59 \mathrm{a}$ & $5.47 \pm 0.83 \mathrm{~b}$ & $8.44 \pm 3.13 \mathrm{c}$ \\
$21 \mathrm{~d}$ & $14.30 \pm 4.61 \mathrm{a}$ & $24.43 \pm 6.89 \mathrm{a}$ & $3.64 \pm 0.37 \mathrm{~b}$ & $4.20 \pm 1.46 \mathrm{c}$ \\
P-value & 0.277 & 0.403 & 0.003 & $<0.001$ \\
\hline
\end{tabular}

Different letters in the columns represent significant differences among the different points in time verified in Tukey Posttest. 
After the I/R, urine sodium (Table 7) values presented significant differences in females along the different points in time $(p=0.004)$ and between the sexes at 24 hours $(p=0.014)$ and on the $5^{\text {th }}$ day $(\mathrm{p}=0.046)$. Note that females from the $\mathrm{I} / \mathrm{R}$ experimental group presented lower values at 24 hours, with levels increasing from the $5^{\text {th }}$ day on. Males, in turn, presented lower values on the $7^{\text {th }}$ day and an increase at the end of the assessment.

TABLE 7 - Mean \pm Standard Error of Sodium $(\mathrm{mEq} / \mathrm{L})$ of urine of rats submitted to unilateral left ischemia for 10 minutes and analysis of perfusion 24 hours and 5, 7, 14 and 21 days after the procedure.

\begin{tabular}{ccccc}
\hline \multirow{2}{*}{ Variable/Points in time } & \multicolumn{2}{c}{ Group Control } & \multicolumn{2}{c}{ Group Experiment I/R } \\
\cline { 2 - 5 } & Female & Male & Female & Male \\
\hline 24h & $31.50 \pm 9.91 \mathrm{a}$ & $34.75 \pm 9.26 \mathrm{a}$ & $12.00 \pm 3.67 \mathrm{~b}$ & $44.25 \pm 8.70 \mathrm{a}$ \\
$5 \mathrm{~d}$ & $34.75 \pm 9.26 \mathrm{a}$ & $42.75 \pm 2.56 \mathrm{a}$ & $14.50 \pm 1.32 \mathrm{~b}$ & $32.00 \pm 6.87 \mathrm{a}$ \\
$7 \mathrm{~d}$ & $40.25 \pm 2.84 \mathrm{a}$ & $40.00 \pm 8.93 \mathrm{a}$ & $30.00 \pm 11.81 \mathrm{ab}$ & $26.00 \pm 10.41 \mathrm{a}$ \\
14d & $42.75 \pm 9.19 \mathrm{a}$ & $36.00 \pm 7.84 \mathrm{a}$ & $50.00 \pm 10.84 \mathrm{ab}$ & $67.00 \pm 19.05 \mathrm{a}$ \\
21d & $37.00 \pm 3.67 \mathrm{a}$ & $36.75 \pm 9.06 \mathrm{a}$ & $69.50 \pm 10.37 \mathrm{a}$ & $59.25 \pm 19.10 \mathrm{a}$ \\
P-value & 0.741 & 0.961 & 0.004 & 0.294 \\
\hline
\end{tabular}

Different letters in the columns represent significant differences among the different points in time verified in Tukey Posttest.

There was a significant difference after $\mathrm{I} / \mathrm{R}$ in the levels of fractional excretion of sodium (Table 8 ) between the sexes in the I/R group at 24 hours $(\mathrm{p}=0.017)$. The males presented lower values of FENa in urine at the $7^{\text {th }}$ day, as opposed to the females, who had their highest value at this point. In the control group, FENa values maintained the same pattern.

TABLE 8 - Mean \pm Standard Error of Fraction of Sodium Excretion - FENa (\%) of rats submitted to unilateral left ischemia for 10 minutes and analysis of perfusion 24 hours and 5, 7, 14 and 21 days after the procedure.

\begin{tabular}{ccccc}
\hline \multirow{2}{*}{ Variable/Points in time } & \multicolumn{2}{c}{ Group Control } & \multicolumn{2}{c}{ Group Experiment I/R } \\
\cline { 2 - 5 } & Female & Male & Female & Male \\
\hline 24h & $0.0959 \pm 0.0162 \mathrm{a}$ & $0.1364 \pm 0.3891 \mathrm{a}$ & $0.5301 \pm 0.2989 \mathrm{a}$ & $2.7556 \pm 0.6092 \mathrm{a}$ \\
$5 \mathrm{~d}$ & $0.4208 \pm 0.1743 \mathrm{a}$ & $0.2690 \pm 0.3778 \mathrm{a}$ & $1.1853 \pm 0.2656 \mathrm{a}$ & $1.9841 \pm 0.5984 \mathrm{a}$ \\
$7 \mathrm{~d}$ & $0.2770 \pm 0.0442 \mathrm{a}$ & $0.2638 \pm 0.0445 \mathrm{a}$ & $2.3011 \pm 2.0704 \mathrm{a}$ & $0.4385 \pm 0.2678 \mathrm{a}$ \\
14d & $0.2708 \pm 0.0495 \mathrm{a}$ & $0.3401 \pm 0.0925 \mathrm{a}$ & $0.6071 \pm 0.2428 \mathrm{a}$ & $1.0589 \pm 0.2908 \mathrm{a}$ \\
21d & $0.3656 \pm 0.1197 \mathrm{a}$ & $0.3901 \pm 0.1647 \mathrm{a}$ & $1.4723 \pm 0.3621 \mathrm{a}$ & $1.3011 \pm 0.5212 \mathrm{a}$ \\
P-value & 0.296 & 0.32 & 0.694 & 0.053 \\
\hline
\end{tabular}

Different letters in the columns represent significant differences among the different points in time verified in Tukey Posttest.

In this study, I/R showed mild change in the levels of urine potassium (Table 9) in males and females at all points in time, though with no significant differences $(p>0.05)$.

TABLE 9 - Mean \pm Standard Error of Potassium (mmol/L) of urine of rats submitted to unilateral left ischemia for 10 minutes and analysis of perfusion 24 hours and 5, 7, 14 and 21 days after the procedure.

\begin{tabular}{ccccc}
\hline \multirow{2}{*}{ Variable/Points in time } & \multicolumn{2}{c}{ Group Control } & \multicolumn{2}{c}{ Group Experiment I/R } \\
& Female & Male & $82.43 \pm 32.08 \mathrm{a}$ & $84.55 \pm 18.93 \mathrm{a}$ \\
\hline $24 \mathrm{~h}$ & $117.25 \pm 9.73 \mathrm{a}$ & $124.53 \pm 13.42 \mathrm{a}$ & $45.95 \pm 7.29 \mathrm{a}$ & $76.50 \pm 26.71 \mathrm{a}$ \\
$5 \mathrm{~d}$ & $79.00 \pm 14.18 \mathrm{a}$ & $123.33 \pm 12.70 \mathrm{a}$ & $85.58 \pm 25.65 \mathrm{a}$ & $72.63 \pm 21.56 \mathrm{a}$ \\
$1 \mathrm{~d}$ & $133.78 \pm 17.77 \mathrm{a}$ & $110.80 \pm 11.01 \mathrm{a}$ & $94.50 \pm 19.77 \mathrm{a}$ & $94.35 \pm 11.87 \mathrm{a}$ \\
21d & $129.83 \pm 20.90 \mathrm{a}$ & $91.15 \pm 21.78 \mathrm{a}$ & $96.03 \pm 7.04 \mathrm{a}$ & $89.63 \pm 22.84 \mathrm{a}$ \\
P-value & $124.33 \pm 14.68 \mathrm{a}$ & $71.25 \pm 7.66 \mathrm{a}$ & 0.308 & 0.953 \\
\hline
\end{tabular}

Different letters in the columns represent significant differences among the different points in time verified in Tukey Posttest.
Similar variation also occurred among the animals in the control group on the $21^{\text {st }}$ day $(\mathrm{p}=0.018)$. 
There was significant difference in the fractional excretion of potassium (FEK) (Table 10), with high levels at 24 hours, a progressive decrease after 7 days and a mild increase at 21 days ( $>0.05)$, though with levels close to those presented by the control group.

TABLE 10 - Mean \pm Standard Error of Fraction of Potassium Excretion - FEK (\%) of rats submitted to unilateral left ischemia for 10 minutes and analysis of perfusion 24 hours and 5, 7, 14 and 21 days after the procedure.

\begin{tabular}{ccccc}
\hline \multirow{2}{*}{ Variable/Points in time } & \multicolumn{2}{c}{ Group Control } & \multicolumn{2}{c}{ Group Experiment I/R } \\
\cline { 2 - 5 } & Female & Male & Female & Male \\
\hline $24 \mathrm{~h}$ & $10.5435 \pm 1.2560 \mathrm{a}$ & $15.0229 \pm 2.7042 \mathrm{a}$ & $115.3520 \pm 71.7208 \mathrm{a}$ & $190.3053 \pm 69.2530 \mathrm{a}$ \\
$5 \mathrm{~d}$ & $17.3556 \pm 3.5505 \mathrm{a}$ & $19.9210 \pm 4.5825 \mathrm{a}$ & $143.7500 \pm 41.2308 \mathrm{a}$ & $143.5296 \pm 46.0116 \mathrm{a}$ \\
$7 \mathrm{~d}$ & $31.2378 \pm 5.9191 \mathrm{a}$ & $24.0426 \pm 5.5554 \mathrm{a}$ & $36.4478 \pm 12.1515 \mathrm{a}$ & $33.4435 \pm 15.8311 \mathrm{a}$ \\
$14 \mathrm{~d}$ & $30.1706 \pm 7.9047 \mathrm{a}$ & $25.9229 \pm 5.0526 \mathrm{a}$ & $39.1868 \pm 13.9763 \mathrm{a}$ & $42.9311 \pm 3.5202 \mathrm{a}$ \\
$21 \mathrm{~d}$ & $34.5182 \pm 10.2301 \mathrm{a}$ & $18.2756 \pm 3.6026 \mathrm{a}$ & $71.0593 \pm 21.5461 \mathrm{a}$ & $62.3750 \pm 18.09113 \mathrm{a}$ \\
P-value & 0.138 & 0.49 & 0.204 & 0.06 \\
\hline
\end{tabular}

Different letters in the columns represent significant differences among the different points in time verified in Tukey Posttest.

Glucose (Table 11) values in the urine of males from the $\mathrm{I} / \mathrm{R}$ experimental group increased from the $1^{\text {st }}$ to the $21^{\text {st }}$ day of assessment; statistical differences were observed between males and females on the $7^{\text {th }}$ day $(\mathrm{p}=0.040)$.

TABLE 11 - Mean \pm Standard Error of Glucose (mg/dL) of urine of rats submitted to unilateral left ischemia for 10 minutes and analysis of perfusion 24 hours and 5, 7, 14 and 21 days after the procedure.

\begin{tabular}{ccccc}
\hline \multirow{2}{*}{ Variable/Points in time } & \multicolumn{2}{c}{ Group Control } & \multicolumn{2}{c}{ Group Experiment I/R } \\
\cline { 2 - 5 } & Female & Male & \multicolumn{2}{c}{ Female } \\
\hline $24 \mathrm{~h}$ & $4.75 \pm 1.11 \mathrm{a}$ & $3.50 \pm 1.50 \mathrm{a}$ & $23.25 \pm 7.11 \mathrm{a}$ & $27.50 \pm 10.30 \mathrm{~b}$ \\
$5 \mathrm{~d}$ & $4.00 \pm 0.58 \mathrm{a}$ & $3.25 \pm 1.03 \mathrm{a}$ & $13.50 \pm 4.97 \mathrm{a}$ & $30.00 \pm 10.58 \mathrm{~b}$ \\
$7 \mathrm{~d}$ & $1.75 \pm 1.18 \mathrm{a}$ & $0.75 \pm 0.25 \mathrm{a}$ & $10.00 \pm 6.38 \mathrm{a}$ & $62.75 \pm 19.15 \mathrm{ab}$ \\
$14 \mathrm{~d}$ & $2.75 \pm 0.63 \mathrm{a}$ & $3.25 \pm 1.11 \mathrm{a}$ & $26.50 \pm 9.85 \mathrm{a}$ & $66.75 \pm 21.32 \mathrm{ab}$ \\
$21 \mathrm{~d}$ & $2.75 \pm 0.48 \mathrm{a}$ & $5.25 \pm 1.25 \mathrm{a}$ & $37.00 \pm 29.69 \mathrm{a}$ & $97.75 \pm 29.51 \mathrm{a}$ \\
P-value & 0.175 & 0.198 & 0.594 & 0.006 \\
\hline
\end{tabular}

Different letters in the columns represent significant differences among the different points in time verified in Tukey Posttest.

$\mathrm{I} / \mathrm{R}$ promoted variations in the urine flow (Table 12) compared to the control group at 24 hours and 5 days after I/R. The of animals submitted to the ischemia model by clamping when variation was more intense among the males.

TABLE 12 - Mean \pm Standard Error of Urine Flow $(\mathrm{ml} / \mathrm{min})$ of rats submitted to unilateral left ischemia for 10 minutes and analysis of perfusion 24 hours and 5, 7, 14 and 21 days after the procedure.

\begin{tabular}{ccccc}
\hline \multirow{2}{*}{ Variable/Points in time } & \multicolumn{2}{c}{ Group Control } & \multicolumn{2}{c}{ Group Experiment I/R } \\
\cline { 2 - 5 } Female & $0.0078 \pm 0.0014 \mathrm{a}$ & $0.0085 \pm 0.0029 \mathrm{a}$ & $0.0050 \pm 0.0014 \mathrm{a}$ & $0.0055 \pm 0.0020 \mathrm{a}$ \\
$2 \mathrm{~h}$ & $0.0080 \pm 0.0082 \mathrm{a}$ & $0.0133 \pm 0.0043 \mathrm{a}$ & $0.0028 \pm 0.0010 \mathrm{a}$ & $0.0028 \pm 0.0009 \mathrm{a}$ \\
$5 \mathrm{~h}$ & $0.0053 \pm 0.0007 \mathrm{a}$ & $0.0075 \pm 0.0011 \mathrm{a}$ & $0.0055 \pm 0.0012 \mathrm{a}$ & $0.0072 \pm 0.0024 \mathrm{a}$ \\
$7 \mathrm{~d}$ & $0.0068 \pm 0.0007 \mathrm{a}$ & $0.0053 \pm 0.0024 \mathrm{a}$ & $0.0045 \pm 0.0006 \mathrm{a}$ & $0.0038 \pm 0.0011 \mathrm{a}$ \\
$14 \mathrm{~d}$ & $0.0065 \pm 0.0015 \mathrm{a}$ & $0.0073 \pm 0.0018 \mathrm{a}$ & $0.0045 \pm 0.000 \mathrm{a}$ & $0.0053 \pm 0.0016 \mathrm{a}$ \\
$21 \mathrm{~d}$ & $0.0045 \pm 0.0013 \mathrm{a}$ & $0.0058 \pm 0.0026 \mathrm{a}$ & $0.0055 \pm 0.0016 \mathrm{a}$ & $0.0062 \pm 0.0014 \mathrm{a}$ \\
P-value & 0.146 & 0.097 & 0.428 & 0.429 \\
\hline
\end{tabular}

Different letters in the columns represent significant differences among the different points in time verified in Tukey Posttest. 
The $\mathrm{I} / \mathrm{R}$ effect on the urine protein-to-creatinine ratio (Table 13) was accentuated among the males at 24 hours and increased up to the $7^{\text {th }}$ day. These levels remained accentuated up to the $21^{\text {st }}$ day among the females. In the control group, the UP/ $\mathrm{UCr}$ ratio remained lower and more constant.

TABLE 13 - Mean of urine protein $(\mathrm{mg} / \mathrm{dL})$-to-creatinine $(\mathrm{mg} / \mathrm{dL})$ ratio of rats submitted to unilateral left ischemia for 10 minutes and analysis of perfusion 24 hours and 5, 7, 14 and 21 days after the procedure.

\begin{tabular}{ccccc}
\hline \multirow{2}{*}{ Momento } & \multicolumn{2}{c}{ Group Control } & \multicolumn{2}{c}{ Group Experiment I/R } \\
\cline { 2 - 5 } & Female & Male & 6,31 & Male \\
\hline $24 \mathrm{~h}$ & 0,24 & 0,64 & 13,08 & 12,67 \\
$5 \mathrm{~d}$ & 0,22 & 0,38 & 4,45 & 12,77 \\
$7 \mathrm{~d}$ & 0,23 & 0,63 & 2,21 & 5,71 \\
$14 \mathrm{~d}$ & 0,31 & 0,56 & 5,51 & 4,5 \\
$21 \mathrm{~d}$ & 0,49 & 0,36 & & 4,62 \\
\hline
\end{tabular}

In regard to the macroscopic aspect of the kidneys submitted to ischemia and reperfusion, no significant changes were observed concerning their aspect, size or volume in either females or males. The change of color observed in the kidneys

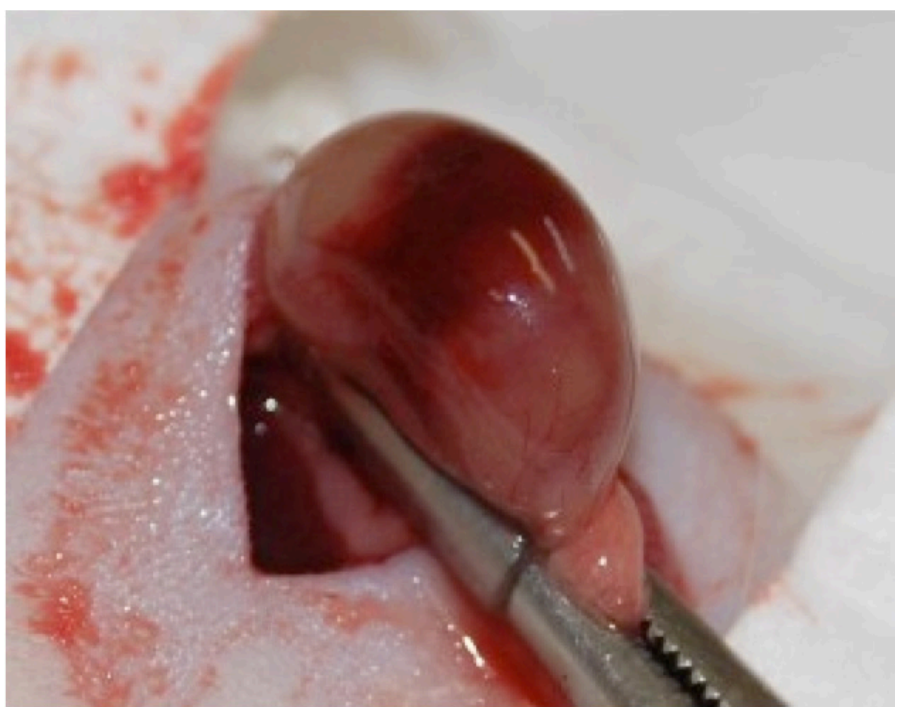

FIGURE 1 - Color in the left kidney 5 minutes after the ischemia procedure.

As for the histopathological assessment, congestion was observed in the cortical region in $75 \%$ of the samples of left kidneys of the females submitted to $I / R$, while this percentage among the males was $50 \%$. Discrete tubular degeneration was observed in $50 \%$ of the medullar region and in $25 \%$ of the cortical region of the left kidney of females; the inverse occurred among the males. Moderate tubular degeneration was observed in 50\% of the cortical and medullar region of the females' kidneys, while at the time of the surgery when ischemia was performed was evident. Figures 1 and 2 show the change of color of the left kidney at $5 \mathrm{~min}$ and $10 \mathrm{~min}$, respectively, during the surgical procedure.

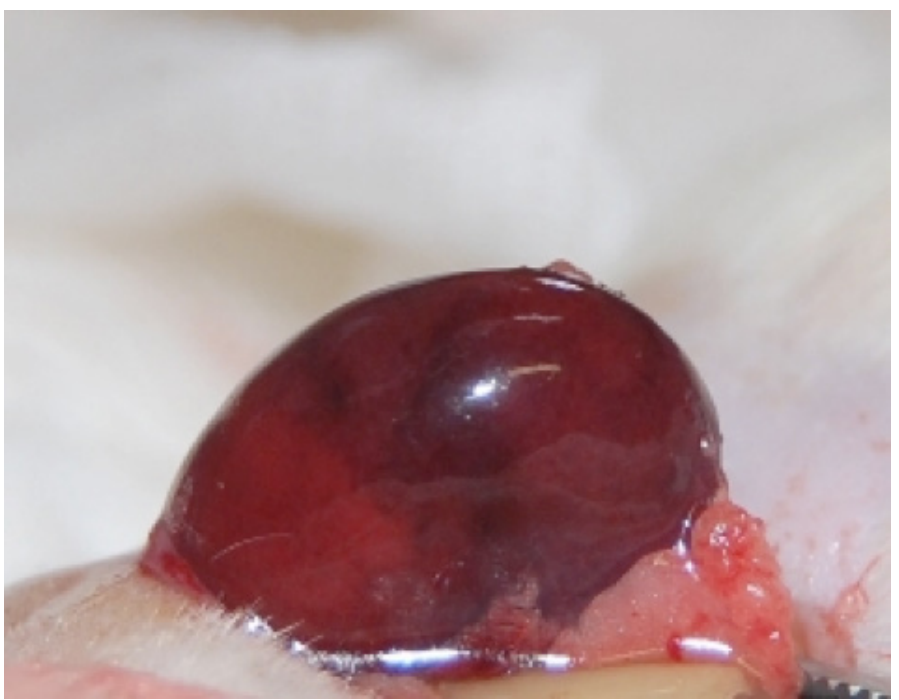

FIGURE 2 - Color in the left kidney 10 minutes after the ischemia procedure.

among the males' kidneys, $75 \%$ of moderate tubular degeneration was observed in the medullar region and $50 \%$ in the cortical region. Only mild congestion was observed in the cortical region of contralateral kidneys when compared with the kidneys submitted to $\mathrm{I} / \mathrm{R}$ for 10 minutes.

The statistical analysis of the left kidneys' weight in the $\mathrm{I} / \mathrm{R}$ experimental group revealed differences between sexes in regard to weight, length and width $(\mathrm{p}<0.001)$. The significant 
differences observed among the females concerned the kidneys' weight $(\mathrm{p}=0.015)$, while among the males, differences concerned the kidneys' weight $(\mathrm{p}=0.002)$ and width $(\mathrm{p}<0.001)$. Differences between sexes within the I/R group concerned the kidney's weight $(p=0.043)$ and length $(p=0.017)$. Therefore, $I / R$ interfered in these measures both in regard to the left kidney, the one submitted to ischemia, verified by histopathological analysis, and in regard to the contralateral kidney, in which the differences observed were between sexes in regard to weight $(p=0.001)$, length $(p=0.005)$, and width $(\mathrm{p}=0.017)$.

\section{Discussion}

Bussmann et al. ${ }^{7}$ report that the duration of ischemia directly influences the levels of plasma creatinine and degree of renal injury: plasma creatinine levels increased twice after 25 minutes of ischemia and seven to eight times after 45 minutes, which is associated with significant necrosis. This information was important in this study to induce ischemia for a shorter period, ten minutes, in order to minimize injuries.

According to Leal et al. ${ }^{8}, \mathrm{I} / \mathrm{R}$ induced-injury in kidneys is the main etiological factor of acute kidney failure (ARF), which is characterized, among other findings, by the transitory increase in serum creatinine rates at the first 24 hours $(3.45 \pm 0.69 \mathrm{mg} / \mathrm{dL})$ after reperfusion and the decrease on the $7^{\text {th }}$ day $(1.78 \pm 0.58 \mathrm{mg} /$ $\mathrm{dL}$ ). These values differ from this study because a tendency of increased values of serum creatinine in the I/R group ranging from $0.30 \pm 0.00$ to $0.55 \pm 0.03 \mathrm{mg} / \mathrm{dL}$ was observed with a percentage increase of $1.65 \%$ at 24 hours and $1.5 \%$ on the $5^{\text {th }}$ and $7^{\text {th }}$ days for both sexes; increases of $2 \%$ and $2.75 \%$ were observed on the $14^{\text {th }}$ and $21^{\text {st }}$ days, respectively, for both sexes. On the $14^{\text {th }}$ and $21^{\text {st }}$ days both sexes experienced increases of $2 \%$ and $2.75 \%$, respectively, but these increases were between $2 \%$ and $2.4 \%$ in the males. A similar percentage increase was observed in the $\mathrm{I} / \mathrm{R}$ experimental group. Serum creatinine increased in both groups, thus, there is a chance there was an increase in muscle mass, since a more significant weight gain was verified in the control group compared to the I/R group, which lost weight in the first week post surgery.

Even if the serum creatinine parameters remained within normal ranges, there was a significant percentage increase, which leads to the RIFLE or AKIN classification that suggests a risk of acute kidney injury in the animals, which underwent ischemia for a period of 10 minutes and were assessed from 24 hours up to 21 days after reperfusion. Additionally, Kellum et $a l .{ }^{9}$ suggest the use of acute kidney injury instead of acute kidney failure because it is more comprehensive and includes mild changes in kidney function. Cruz et al. ${ }^{10}$ infer that the RIFLE/ AKIN classification requires new biomarkers to be consensually used by the medical profession.

The new parameters that are used to show the presence of protein in urine, as described by Zanella ${ }^{11}$, more specifically consider 24-hour samples, in which levels $<20 \mathrm{mg}$ define normoalbuminuria, from 20 to $199 \mathrm{mg}$ define micro albuminuria, and levels $\geq 200 \mathrm{mg}$ indicate macro albuminuria. In this aspect, the females within the $\mathrm{I} / \mathrm{R}$ group presented the following values $43.44 \pm 2.03$ to $106.16 \pm 5.46 \mathrm{mg}$ and the males $56.01 \pm 4.57$ to $127.80 \pm 3.01 \mathrm{mg}$, therefore, they were classified as having microalbuminuria. These values indicate that $\mathrm{I} / \mathrm{R}$ for 10 minutes influenced an increased rate of albumin excretion in the urine of these animals. The control group was considered normoalbuminuric. The values reported by Sagiroglu et al. ${ }^{12}$ corroborate this study, since they observed 116.6 $\pm 10.2 \mathrm{mg}$ protein in the urine at 24 hours, as high as the level observed in the $\mathrm{I} / \mathrm{R}$ females on the $21^{\text {st }}$ day.

Even though urea is freely filtered by the glomerulus and not reabsorbed nor actively secreted, Sodré et al. ${ }^{13}$ contend it is a weak predictor of the glomerular filtration rate (GFR) because $40 \%$ to $70 \%$ returns to the plasma by a process of passive diffusion, depending on the urine flow. Thus, urine stasis leads to an even greater return of urea in the renal tubules and the computed GRF is underestimated by urea clearance. Levels of $7398 \pm 706 \mathrm{mg} / 24 \mathrm{~h}$ for urine urea were verified by Sagiroglu et al. ${ }^{12}$, which is similar to the levels found in this study, when compared to the I/R males after 21 days. These analyses indicate that I/R for 10 minutes was sufficient to cause an effect, since a gradual but intense increase in urea filtration was observed in both males and females during the experimental period.

GFR is indirectly computed through creatinine clearance (Clcr) and remains one of the most frequently used markers in the assessment of renal function but, according to Sodré et al. ${ }^{13}$, it is difficult to obtain the $24^{\text {th }}$-hour volume. This fact was also observed in this study in the collection of $24^{\text {th }}$-hour samples, even with the use of metabolic cages. Vattimo and Silva ${ }^{14}$ report $0.77 \pm 0.05 \mathrm{~mL} /$ min for creatinine clearance $/ 100 \mathrm{~g}$ while Meyer et al. ${ }^{15}$ report $0.20 \pm 0.02 \mathrm{~mL} / \mathrm{min}$ Clcr and concluded that more than 30 minutes of renal occlusion establishes a higher flow, leading to decreased survival. The values are similar to those observed in this study in the experimental I/R group at 24-hours and on the $21^{\text {st }}$ day after unilateral left ischemia without contralateral nephrectomy.

Andrade et al..$^{16}$ obtained $73 \pm 68 \mathrm{mg} / \mathrm{dL}$ urinary creatinine $(\mathrm{CrU})$ among animals that underwent $\mathrm{I} / \mathrm{R}$ with bilateral clamping of renal pedicles for 30 minutes and weighed $294 \pm 54 \mathrm{~g}$ on average; the ischemia was of longer duration than that performed 
in this study, but weight was similar to this study's subjects. Perhaps if this component is verified within a shorter amount of time after I/R, there will be a significant decrease in renal filtration of creatinine, as observed in this study. Castro et al. ${ }^{17}$ report $88.5 \pm 11.1 \mathrm{mg} / \mathrm{dL} \mathrm{CrU}$ at 24 hours (without fasting) in the normal animals. Note that, regardless of the I/R models, this parameter did not differ. Therefore, the I/R group presented lower renal filtration and even lower GFR at 24 hours and on the $5^{\text {th }}$ day.

ALP urinary activity increased in the I/R group at 24 hours and remained high up to the $5^{\text {th }}$ day. On the $7^{\text {th }}$ day it decreased abruptly, and almost dropping to levels that equaled the levels observed in the control group. This result is in agreement with the results found by $\mathrm{Clemo}^{18}$, for whom the concentration of urine enzymes released by the injured cells of the tubular epithelium is sensitive to the detection of early tubular injury and has the potential to determine the primary locale of renal damage, such as gamma-glutamyl transferase and alkaline phosphatase, which were associated with renal proximal tubular damage in dogs. Palacio et al. ${ }^{19}$ believe that the amount of the enzyme in urine is more sensitive and reliable for the assessment of renal damage because they increase in concentration in urine before than serum creatinine and urea the do. As noted in this study, increased urine excretion of these biomarkers occurred much earlier than changes in classic and established renal markers such as plasma creatinine. This is what happened with the activity of the GGT urine enzyme in animals of the I/R group. Even though the $I / R$ procedure took only 10 minutes, it was enough to injure renal tubular cells, since enzymatic excretion increased, especially in the first hours after the procedure ${ }^{19}$.

Cutrín et al..$^{20}$ report that high enzyme activity has been observed in cells presenting intense excretory and absorptive functions, such as the epithelial cells of the proximal tube, jejunum and biliary tract cells. The study also reports that GGT activity doubled in both cortical and medullar areas after 25 minutes of unilateral ischemia; concluding that renal ischemia in the short term (25 minutes) increases GGT activity and lipid peroxidation, suggesting that ischemia-induced acute kidney injury is related to increased urinary GGT activity. These findings corroborate this study, because GGT was high at the first 24-hour point.

There was decreased fractional excretion of sodium at 24 hours and up to five days after I/R. A progressive increase occurred after seven days. According to Draibe and Cendoroglo ${ }^{21}$, there are, during the course of renal failure, progressive increases in urea and creatinine, while concentrations of $\mathrm{Na}$ and $\mathrm{K}$ ions are very close to normal with a progressive decrease of plasma bicarbonate and a less evident decrease in ph.
In regard to ischemic acute kidney injury, Andrade et al. ${ }^{16}$ observed the comparative effect of two antioxidants when they used 14 male Wistar adult rats weighing $294 \pm 54 \mathrm{~g}$ and submitted to $\mathrm{I} / \mathrm{R}$ by bilateral clamping of renal pedicles for 30 minutes. These animals presented fractional excretion of sodium (FENa) at $0.18 \pm 0.02 \%$. Lower levels were observed in the I/R group, but similar to those observed among the females in the control group at 24 hours.

Alterations were observed in urine potassium levels between the sexes in the control group on the $21^{\text {st }}$ day and are in agreement with the findings of Draibe and Cendoroglo ${ }^{21}$, where the concentrations of $\mathrm{Na}$ and $\mathrm{K}$ during renal failure are very close to normal. The level of urine potassium verified by Sagiroglu et al. ${ }^{12}$ at 24 hours was $143.1 \pm 1.2 \mathrm{mEq} / 24 \mathrm{~h}$ among animals undergoing $\mathrm{I} / \mathrm{R}$, which is much higher than the levels found in this study.

The fraction of potassium excretion (FEK) and the urinary concentration of this electrolyte are modified by aldosterone and potassium intake. The fractional excretion in this study varied in both sexes in the I/R group, which presented a sharp increase at 24 hours and decreasing reduction up to 21 days. For Maciel et $a l .^{22}$ the fraction of potassium excretion may signal decreases in the rate of glomerular filtration even before serum creatinine increases. These findings are similar to those reported in this study, in which there was a sharp increase in this parameter at the first 24-hour point.

In regard to urinary glucose, the entire amount filtered by the renal glomeruli is absorbed by the proximal convoluted tubules. Thus, since there was not $100 \%$ reabsorption because a tendency to have decreased serum glucose levels was observed in the I/R group over time, we infer that glucose was eliminated by the urine. This confirms that there was no injury in the proximal tubules caused by the 10-minute I/R. These findings together with the urine enzyme values, show the risk of AKI after I/R for this period of time.

Regarding urine flow, Vattimo and Silva ${ }^{14}$ observed $0.00176 \pm 0.004 \mathrm{~mL} / \mathrm{min}$ in animals in the $\mathrm{I} / \mathrm{R}$ group, weighing $299 \pm 32 \mathrm{~g}$, similar to what was observed in this study. Meyer et al. ${ }^{15}$ concluded that 30 minutes of renal occlusion establishes a higher urine flow in comparison to kidneys submitted to a 60-minute ischemia, which resulted in decreased survival. In this study, there were variations in the urine flow in the I/R group at 24 hours and on the $5^{\text {th }}$ day, with a sharp increase on the $7^{\text {th }}$ day, which coincides with the period of recovery of renal tubular cells; on the $21^{\text {st }}$ day, levels became similar to those observed in the control group.

The UP/UCr ratios were below 1 and even below 0.5 . Menezes et al. ${ }^{23}$ note that assessment of the $\mathrm{UP} / \mathrm{UCr}$ ratio and 
GGT urine activity are more sensitive exams than the routine urine exam in detecting acute tubular injury (ATI), since these variables present changes before serum urea and creatinine. In this study, the UP/UCr ratios observed in the $\mathrm{I} / \mathrm{R}$ animals were higher than in the control group at 24 hours, and at five and seven days, with a tendency to return to normal levels on the $14^{\text {th }}$ and $21^{\text {st }}$ days, possibly indicating the increased excretion of protein in urine and a potential risk of (ATI) in the first days, with subsequent regeneration.

Regarding the macroscopic aspect of kidneys, Konopka et $a l .{ }^{24}$ reported that the group submitted to $\mathrm{I} / \mathrm{R}$ presented a progressive reduction in renal weight and volume from the $7^{\text {th }}$ day on and reached the maximum degree on the $49^{\text {th }}$ day $(p<0.05)$. In this study, while the left kidneys of the control animals presented proper and significant differences in weight, length and width $(p<0.001)$ between sexes, the animals from the experimental group submitted to $\mathrm{I} / \mathrm{R}$ did not present significant differences in terms of length $(p=0.161)$ and width $(p=0.207)$, and were smaller than those of the control animals. In regard to the left kidneys' weight, significant difference $(p=0.008)$ was observed between sexes of the individuals in the experimental group within the period of the first 21 days, as well as between the males' $(p=0.002)$ and females' $(\mathrm{p}=0.015)$ kidneys.

For the histopathological assessment in this study, we considered microscopic changes of kidneys found in the animals from the I/R group and compared them with those found in the contralateral kidneys. According to Konopka et al. ${ }^{24}$, the model of chronic renal ischemia in rats causes progressive renal atrophy with preserved glomerular structure, which according to this study, depends proportionally on the duration of ischemia for the kidneys and on the deleterious effects of reperfusion.

\section{Conclusions}

Ten minutes of renal ischemia raised the levels of urine protein, urea, glucose, fractional excretion of potassium and urea, creatinine clearance and urine activity of the alkaline phosphatase and gamma-glutamyl transferase enzymes, more intensively in the first 24 hours and up to five days after reperfusion. The protein-to-creatinine ratio significantly increased after ischemia in both sexes. In addition to sex and weight, age also affected the parameters assessed.

\section{References}

1. Heyman SN, Rosenberger C, Rosen S. Experimental ischemiareperfusion: biases and myths - the proximal vs. distal hypoxic tubular injury debate revisited. Kidney Int. 2010 Jan;77(1):916. doi: 10.1038/ki.2009.347

2. Bernardi RM, Constantino L, Machado RA, Vuolo F, Budni P, Ritter C, Dal-Pizzol F. N-acetylcysteine and deferrioxamine protects against acute renal failure induced by ischemia/reperfusion in rats. Rev Bras Ter intensiva. 2012 Set;24(3):219-23. doi: 10.1590/S0103507X2012000300003.

3. Tanaka R, Takayama J, Takaoka M, Sugino Y, Ohkita M, Matsumura Y. Oligomycin, an F1FO-ATPase inhibitor, protects against ischemic acute kidney injury in male but not in female rats. J Pharmacol Sci. 2013 Nov;123(3):227-34. doi: 10.1254/jphs.13069FP.

4. Bellomo R, Ronco C, Kellum JA, Mehta RL, Palevsky P. Acute renal failure - definition, outcome measures, animal models, fluid therapy and information technology needs: the Second International Consensus Conference of the Acute Dialysis Quality Initiative (ADQI) Group. Crit Care. 2004 May;8(4):204-12. doi: 10.1186/ cc2872.

5. Gonçales LN, Paoliello MMB, Janeiro V, Machinski JM. N-acetil$\beta$-D-glicosaminidase como biomarcador precoce de disfunção renal para a exposição ocupacional ao chumbo inorgânico. J Bras Patol Med Lab. 2008 Aug;44(4):241-7. doi: 10.1590/S167624442008000400003.

6. Mehta RL, Kellum JA, Shah SV, Molitoris BA, Ronco C, Warnock DG, Levin A; Acute Kidney Injury Network. Acute Kidney Injury Network: report of an initiative to improve outcomes in acute kidney injury. Crit Care. 2007 Mar;11(2):31-8. doi: 10.1186/cc5713.

7. Bussmann AR, Filho MAM, Módolo MP, Módolo R P, Amado P, Domingues MAC, Castiglia YMM, Módolo NSP. Effect of allopurinol on the kidney function, histology and injury biomarker (NGAL, IL 18) levels in uninephrectomised rats subjected to ischaemia-reperfusion injury. Acta Cir Bras. 2014 Ago;29(8):51521. doi.10.1590/ S0102-86502014000800006.

8. Leal DM, Júnior ST, Suaid HJ, Cologna AJ, Martins ACP, Roselino JES. Proteção funcional do rim com lovastatina após isquemia e reperfusão renal. Acta Cir Bras. 2001;16(Suppl 1):23-6. doi. org/10.1590/S0102-86502001000500009.

9. Kellum JA, Levin N, Bouman C, Lameire N. Developing a consensus classification system for acute renal failure. Curr Opin Crit Care. 2002 Dec;8(6):509-14. PMID: 12454534.

10. Cruz DN, Ricci Z, Ronco C. Clinical review: RIFLE and AKIN - time for reappraisal. Critical Care. 2009 Jun;13(3):211-20. doi:10.1186/cc7759.

11. Zanella MT. Microalbuminúria: fator de risco cardiovascular e renal subestimado na prática clínica. Arq Bras Endocrinol Metab. 2006 Apr;50(2):313-21. doi: 10.1590/S0004-27302006000200017.

12. Sagiroglu T, Sezer A, Torun N, Yalta T, Yagci MA, Sagiroglu G, Copuroglu E. Protective effect of everolimus on renal ischemia reperfusion injury in rats. Saudi J Kidney Dis Transpl. 2014 Mar;25(2):294-302. PMID: 24625994.

13. Sodré FL, Costa JCB, Lima JCC. Avaliação da função e da lesão renal: um desafio laboratorial. J Bras Patol Med Lab. 2007 Out:43(5):329-37. doi: 1590/S1676-24442007000500005.

14. Vattimo MFF, Silva NO. Uncária tomentosa e a lesão renal aguda isquêmica em ratos. Rev Esc Enferm USP. 2011 Mar;45(1):194-8. doi: 10.1590/S0080-62342011000100027.

15. Meyer F, Silva DS, Bombonatto GM, Navarro LJ, Dziedricki LF, Krieger ML. Histological analysis and the blood flux in kidneys submitted to different periods of ischemia/reperfusion. Acta Cir Bras. 2011 Nov/Dec;26(6):451-5. doi: 10.1590/S010286502011000600008.

16. Andrade SC, Dezoti C, Shibuya C A, Watanabe M, Vattimo MF. Efeito protetor renal do Alopurinol e N-Acetilcisteína. J Bras Nefrol. 2004 Jun; 26(2):69-75. 
17. Castro BBA, Colugnati FAB, Cenedeze MA, Suassuna PGA, Pinheiro HS. Standardization of renal function evaluation in Wistar rats (Rattus norvegicus) from the Federal University of Juiz de Fora's colony. J Bras Nefrol. 2014 Apr/June;36(2):139-49. doi: 10.5935/0101-2800.20140023.

18. Clemo FAS. Urinary enzyme evaluation of nephrotoxicity in the dog. Toxicol Pathol. 1998 Jan/Feb;26(1):29-32. doi: $10.1177 / 019262339802600104$.

19. Palacio J, Liste F, Gascon M. Enzymuria as an index of renal damage in canine leishmaniasis. Vet Rec. 1997 May;140(18):477-80. PMID: 9160531.

20. Cutrín JC, Zingaro B, Camandola S, Boveris A, Pompella A, Poli G. Contribution of gamma glutamyl transpeptidase to oxidative damage of ischemic rat kidney. Kidney Int. 2000 Feb;57(2):526-33. doi: 10.1046/j.1523-1755. 2000.00871.

21. Draibe SA, Cendoroglo M. Tratamento conservador da insuficiência renal crônica. Rev Diagn Tratamento. 2001;6(2):17-23. ID: li1320514.

22. Maciel AT, Park M, Macedo E. Fração de excreção de potássio na evolução da lesão renal aguda em pacientes graves: um potencial marcador a ser onitorizado? Rev Bras Ter Intensiva. 2014 Apr/ June;26(2):143-7. doi: 10.5935/0103-507X. 2014002.

23. Menezes LB, Fioravanti MCS, Silva MSB, Franco LG, Sales TP, Andrascko MM, Veado JCC, Araújo EG. Avaliação do efeito da clorpromazina sobre a função renal de cães submetidos à isquemia e reperfusão. Pesq Vet Bras. 2010;30(2):108-14. doi: 10.1590/S0100736X2010000200002.

24. Konopka CL, Jurach A, Wender OCB. Experimental model for the study of chronic renal ischemia in rats: morphologic, histological and ultra-structural analysis. Acta Cir Bras. 2007 Feb;22(1):12-21. doi: 10.1590/S0102-8650200 7000100003 .

\section{Acknowledgement}

The Biological and Health Sciences Center (UFMS) for providing the physical structure and qualified professionals of the Animal Facility, Prof. Louisiane de Carvalho Nunes, and the Laboratory of Clinical Analysis (UFES).

\section{Correspondence:}

Iandara Schettert Silva

Avenida Senador Filinto Muller, s/n - Cidade Universitária 79080-190 Campo Grande - MS Brasil

ian.da.ra@hotmail.com

Received: Dec 19, 2014

Review: Feb 20, 2015

Accepted: Mar 18, 2015

Conflict of interest: none

Financial source: Foundation for Support to Development of Education, Science and Technology of the State of Mato Grosso do Sul (FUNDECT). Process No. 23/200.129/2011 (T.O. 0020/11).

${ }^{1}$ Research performed at Department of Experimental Animal Facility, Biological and Health Sciences Center, Federal University of Mato Grosso do Sul (UFMS), Campo Grande-MS, Brazil. Part of PhD degree thesis, Postgraduate Program in Health and Development of the Midwest, UFMS. Tutor: Iandara Schettert Silva. 